\title{
The oral VEGF receptor tyrosine kinase inhibitor pazopanib in combination with the MEK inhibitor trametinib in advanced cholangiocarcinoma
}

\author{
Rachna T Shroff ${ }^{1,4}$, Mark Yarchoan ${ }^{2,4}$, Ashley O'Connor ${ }^{2}$, Denise Gallagher ${ }^{2}$, Marianna L Zahurak ${ }^{2}$, \\ Gary Rosner ${ }^{2}$, Chimela Ohaji ${ }^{1}$, Susan Sartorius-Mergenthaler ${ }^{2}$, Rose Parkinson ${ }^{3}$, Vivek Subbiah ${ }^{1}$, Ralph Zinner ${ }^{1}$ \\ and Nilofer S Azad ${ }^{2}$ \\ ${ }^{1}$ The University of Texas MD Anderson Cancer Center, 1515 Holcombe Boulevard Unit 426, Houston, TX 77030, USA; \\ ${ }^{2}$ Gastrointestinal Oncology, Sidney Kimmel Comprehensive Cancer Center, Johns Hopkins University, 1650 Orleans Street, Room \\ 4M10, Baltimore, MD 21287, USA and ${ }^{3}$ The Sidney Kimmel Comprehensive Cancer Center, Johns Hopkins University, 1650 \\ Orleans Street, Room 4M10, Baltimore, MD 21287, USA
}

Correction to: British Journal of Cancer (2017) 116, 1402-1407. doi:10.1038/bjc.2017.119; published online 25 April 2017

The authors would like to add Dr Rose Parkinson to the author list. She now appears in the author list, and her affiliation is also provided, above.

The authors would like to change the acknowledgments to the following:

'We thank the patients and their families for participating in this study and the clinical staff at Johns Hopkins and MD Anderson Cancer Center for their clinical care and data collection.'

The authors would also like to correct Table 2; the updated table is shown below. To reflect the updated table, the authors would also like to make changes to the 'Adverse events' section of the Results. The second sentence of the second paragraph should now read:
'Treatment-related toxicities were predominantly of mild or moderate severity, with the most common events including rash (76\% of patients), hypertension $(60 \%)$, nausea or vomiting (64\%), fatigue (60\%), diarrhoea $(60 \%)$, and thrombocytopenia (40\%).'

Despite the changes to Table 2 and the associated text, the authors state that the conclusions put forth in this article, including the safety of this regimen, remain unchanged.

This work is published under the standard license to publish agreement. After 12 months the work will become freely available and the license terms will switch to a Creative Commons AttributionNonCommercial-Share Alike 4.0 Unported License.

\footnotetext{
${ }^{4}$ These authors contributed equally to this work. Published online 9 January 2018

(C) 2018 Cancer Research UK. All rights reserved 0007-0920/18
} 
Table 2. Treatment-related adverse events occurring in two or more participants, and all grade $\frac{3}{4}$ treatment-related

adverse events

\begin{tabular}{|c|c|c|c|c|}
\hline & \multicolumn{2}{|c|}{ Any grade } & \multicolumn{2}{|c|}{ Grade 3-4 } \\
\hline Event & $\begin{array}{c}\text { No of } \\
\text { patients }\end{array}$ & $\%$ & $\begin{array}{c}\text { No of } \\
\text { patients }\end{array}$ & $\%$ \\
\hline \multicolumn{5}{|l|}{ Cardio-renal } \\
\hline Oedema, facial & 3 & $12 \%$ & \multirow{7}{*}{2} & \multirow{7}{*}{$8 \%$} \\
\hline Oedema, limbs & 4 & $16 \%$ & & \\
\hline Elevated creatinine & 2 & $8 \%$ & & \\
\hline Hypertension & 15 & $60 \%$ & & \\
\hline Hypomagnesemia & 6 & $24 \%$ & & \\
\hline Hyponatremia & 2 & $8 \%$ & & \\
\hline Proteinuria & 3 & $12 \%$ & & \\
\hline \multicolumn{5}{|l|}{ Constitutional } \\
\hline Dehydration & 2 & $8 \%$ & & \\
\hline Fatigue & 15 & $60 \%$ & 2 & $8 \%$ \\
\hline \multicolumn{5}{|l|}{ Dermatologic } \\
\hline Dry skin & 3 & $12 \%$ & \multirow[b]{3}{*}{3} & \multirow[b]{3}{*}{$12 \%$} \\
\hline Finger or nail changes & 3 & $12 \%$ & & \\
\hline Rash & 19 & $76 \%$ & & \\
\hline \multicolumn{5}{|l|}{ Gastrointestinal } \\
\hline Anorexia & 9 & $36 \%$ & & \multirow{4}{*}{$\begin{array}{r}4 \% \\
12 \%\end{array}$} \\
\hline Constipation & 3 & $12 \%$ & & \\
\hline Diarrhoea & 15 & $60 \%$ & 1 & \\
\hline Elevated liver function tests & 6 & $24 \%$ & 3 & \\
\hline Mucositis & 2 & $8 \%$ & & \\
\hline Nausea or vomiting & 16 & $64 \%$ & 2 & $8 \%$ \\
\hline \multicolumn{5}{|l|}{ HEENT } \\
\hline Blurry vision/vision changes & 5 & $20 \%$ & & \\
\hline Change in taste & 7 & $28 \%$ & & \\
\hline Congestion or post-nasal drip & 2 & $8 \%$ & & \\
\hline Floaters & 2 & $8 \%$ & & \\
\hline \multicolumn{5}{|l|}{ Haematologic } \\
\hline Anemia & 2 & $8 \%$ & \multirow[t]{3}{*}{1} & \multirow[t]{3}{*}{$4 \%$} \\
\hline Bleeding or bruising & 7 & $28 \%$ & & \\
\hline Neutropenia & 3 & $12 \%$ & & \\
\hline Thrombocytopenia & 10 & $40 \%$ & 6 & $24 \%$ \\
\hline \multicolumn{5}{|l|}{ Neurological } \\
\hline Amnesia & 1 & $4 \%$ & & \\
\hline Dizziness & 2 & $8 \%$ & & \\
\hline Headache & 2 & $8 \%$ & & \\
\hline $\begin{array}{l}\text { Posterior reversible } \\
\text { encephalopathy syndrome (PRES) }\end{array}$ & 1 & $4 \%$ & 1 & $4 \%$ \\
\hline
\end{tabular}

